\title{
A GUIDE FOR INTEGRATING TOTAL QUALITY MANAGEMENT AND PHYSICAL ASSET MANAGEMENT IN THE FOOD INDUSTRY
}

\author{
M.A. van Heerden ${ }^{1 \#} \&$ J.L. Jooste ${ }^{1 *}$
}

\section{ARTICLE INFO}

Article details

Submitted by authors 14 Mar 2018

Accepted for publication 23 Oct 2018

Available online $\quad 10$ Dec 2018

\section{Contact details \\ Corresponding author \\ wyhan@sun.ac.za}

Author affiliations

1 Department of Industrial

Engineering, Stellenbosch

University, South Africa

\# The author was enrolled for an $M$ Eng (Industrial) degree in the Department of Industrial Engineering, University of Stellenbosch, South Africa

\section{DOI}

http://dx.doi.org/10.7166/29-4-1944

\begin{abstract}
The integration of an organisation's asset management and total quality management systems has become important in addressing operational challenges in the food industry. This paper proposes a guideline for implementing these systems through an integrated approach that aims to improve product quality. The grounded theory methodology is used to develop a theory based on expert opinions in the South African food and engineering industries. The results are presented in a model in which systems integration is identified as the central phenomenon for improving food quality. Analysis and interpretation of the model is presented in the form of a guideline for managers.
\end{abstract}

\section{OPSOMMING}

Die integrasie van 'n organisasie se batebestuur en totale kwaliteitsbestuurstelsels het belangrik geword om operasionele uitdagings in die voedselindustrie te adresseer. Hierdie artikel stel 'n riglyn voor vir die implementering van hierdie stelsels deur middel van ' $n$ geïntegreerde benadering, met die doel om produkkwaliteit te verbeter. Deur middel van die grondteoriemetodiek word ' $n$ teorie ontwikkel wat gebaseer is op kundiges se opinie binne die Suid-Afrikaanse voedsel- en ingenieursindustrieë. Die resultate word voorgestel in 'n model waar stelselintegrasie dien as die sentrale fenomeen vir voedselkwaliteit-verbetering. Analise en interpretasie van die model word voorgelê in die vorm van 'n riglyn vir bestuurders.

\section{THEORETICAL BACKGROUND}

Food producers have become more focused on the importance of quality due to market competition, governmental regulation, customer demands, and consumer expectations [1,2,3,4]. Over the last thirty years, quality has been identified as an important business driver in the international market. Organisations are therefore becoming more conscious of the competitive potential of quality, and regard it as an approach when competing in the marketplace. The food industry is increasingly pursuing quality management (QM) practices, which include techniques such as quality control (QC) and quality improvement [5]. ISO 9000:2005 defines QM as "coordinated activities to direct and control an organization with regard to quality". This definition of QM is qualified by noting that the "direction and control with regard to quality generally includes establishment of the quality policy and quality objectives, quality planning, QC, Quality Assurance (QA) and Quality Improvement (QI)" [6]. A QM system comprises "the activities and decisions performed in an organization to produce and maintain a product with the desired quality level against minimal costs" [7]. Both of these definitions imply that QM relates to the responsibility of all participants (departments) in the organisation to achieve high-quality products at lower costs [2]. Quality-related events have forced the transformation of QM from a functional focus area to an integrated approach in the management of organisations. The turbulent and market-driven economy forces organisations to adopt management practices that are focused on the continuous and holistic improvement of quality to become cost-effective and responsive in their operations, and to meet and exceed the demands of 
customers $[8,3]$. Total quality management (TQM) has become important in the food industry in addressing these challenges, in a similar way to how it has impacted other industries in the global economy $[3,9]$.

As with other manufacturing industries, the production process of food industries requires the continuous operation of automated production line equipment [10]. Product scrapping, product recalls, and production line downtime caused by equipment failure have organisational and financial implications, and cause production rate variations and quality problems relating to the product $[1,10]$. Production line performance, quality, and availability have therefore remained a priority in the general manufacturing industry, with top management continually required to consider both the impact and the importance of equipment availability and use, resource use, maintenance productivity, and the quality and responsiveness of maintenance services.

The food industry is considered a capital asset-intensive industry, where reliability and productivity are essential factors in the financial success of organisations [11]. An assessment against the European Business Excellence Model (EBQM) reported that the food industry, compared with nonfood manufacturing industries, has the lowest performance $[1,12]$. Consequently, there is an opportunity for the food industry to benchmark itself against their non-food manufacturing peers, and to align itself with the drive to implement new manufacturing programmes and organisational structures to enhance their competitive position.

In the early 2000s, a general agreement about a holistic view of physical asset management (AM) became prevalent in engineering circles. It emphasised lifecycle $A M$, the strategic planning of an $A M$ strategy, asset risk management, optimisation, and other factors of AM such as human, safety, and environmental factors $[13,14]$. As the discipline matured, practitioners became insightful and, recently, have better understood that $A M$ refers to the use of 'assets' to realise value and achieve explicit organisational purposes rather than the mere thought of "doing things to assets" [15]. Once the term 'asset management' ( $A M$ ) is understood, it translates the essential aims of an organisation into the practical implications to choose, to acquire (or create), to use (or operate), and to take care of (or maintain) assets to deliver organisational goals. This translation is accomplished using the best total value approach, which also refers to the optimal combination of costs, risks, performance, and sustainability $[15,16]$.

AM programmes have become an important topic among non-food manufacturing industries that are striving for overall improvement and business excellence. AM is described as a "set of disciplines, methods, procedures and tools to optimise the whole life business impact of costs, performance and risk exposures of the company's assets" [17]. This implies that AM is a holistic management approach. $A M$ is still an unfamiliar discipline for many industry sectors, with the first asset management system (AMS) guideline - in the form of the ISO 55000 series of international standards - only being published in 2014. The concept of AM has been studied globally, and authors stress its importance in achieving business excellence in the transport [18], process [19], construction [14], chemical [20], irrigation [21], service provider, and finance industries [22,23]; but none has yet explored its potential in the food industry.

Integrating $A M$ with the existing TQM programmes in food industries is of interest and deserves further exploration, since there is a limited literature on the topic. AM is focused on asset health and other integrated processes in order to gain lifetime effectiveness, return on assets, and use while risks are considered; it therefore has the potential to facilitate improvement in the turbulent and global market $[24,25]$.

Both TQM and $A M$ are practices that comprise goal-orientated decision-making and production and people-based systems effectively and efficiently to manage the expectations and delivery of quality. Both allow for integration with other associated management approaches, and are flexible enough to be customised as the organisation sees fit [10, 12,21,24,26,27]. There is thus an integration opportunity between TQM and AM that should provide a basis for improvement in the food industry. However, in seeking to integrate AMS with a total quality management system (TQMS) and unlock its potential value, the problem is that no guideline or procedural framework is available to the food industry to assist stakeholders to implement the integration of these systems. This paper presents the results of a grounded theory study that has developed a guideline for the integrated implementation of TQM and $\mathrm{AM}$ and that contributes to quality improvement in the food industry. The results further provide a deeper understanding of the relationship between TQM and AM, 
establishing a foundation from which management can focus their efforts on the practices that facilitate an organisation's ability to establish a competitive QM capability to satisfy customers.

\section{RESEARCH METHODOLOGY}

A qualitative research approach is followed in the study to engage with, and understand, the context in which management approaches the challenge of assuring quality and creating synergy between systems. The exploratory nature of the approach allows for input from managers to generate possible solutions to their current situations. The study follows a pragmatic world-view, which is nonempirical in nature, and in which the grounded theory procedure is adopted as the research design [28]. The methods used as part of the grounded theory design include interviewing; coding; memoing; and visual representation. The process of theory development involves multiple stages of data collection and the refinement and interrelationship of categories of information. This study explores the professional experiences of senior quality and food safety managers, as well as engineering (i.e., maintenance or operations) managers in South African food organisations. All of the professional experiences of the managers in the study are described and interpreted as documented from indepth interviews with nine senior managers from eight different food organisations. Seven of these managers form part of the homogeneous sample, which represents those concerned with food quality and food safety. The roles represented in this sample included a technical manager, a divisional manager, three quality managers, a production manager, and a research and development manager. The two remaining managers form part of the heterogeneous sample, which represents engineering activities. The roles represented in this sample included a maintenance manager and a packaging manager.

For the data collection, a specific protocol was followed. Semi-structured, in-depth, and in-person interviews were conducted with the participants. An initial pilot interview was done to pre-test the quality of the interview protocol. Before each interview, the participants were provided with background material, including a summary of the ISO55000 standard, that had to be studied before the interview. The interviews started with specific probing questions based on the relevant literature about the integration of $A M$ and TQM. Open-ended questions were then posed, allowing the participants the freedom to explain their first-hand experiences relating to the theme. Interviews were recorded for more accurate coding analysis of the transcribed data. The NVivo software for qualitative data analysis was used. In broad terms, the analysis consisted of developing categories of information, interconnecting the categories, and building a 'story' that connects the categories, which finally led to a discursive set of theoretical propositions. The analysis and results of the grounded theory approach led to the development of the guideline to assist management with the integrated implementation of TQM and $A M$.

The grounded theory analysis results in a theory that holistically portrays the expert opinions and inputs for the sample of participants. The theory depicts a gap that is identified, and the conditions, strategies, and consequences for deriving a phenomenon, which is defined as systems integration (SI) of the AMS and TQMS, to close the gap. All the factors that cause the SI to emerge (causal conditions), the actions adopted in response to the emerging SI (coping strategy), the situational factors that influence the strategy (intervening conditions), and the outcomes of using the strategy (consequences) are analysed and interpreted. These factors relate to, support, and explain the SI phenomenon. The theory is represented by the axial coding paradigm in Figure 1 , which is a visual representation of the theory in the form of a theoretical model. The axial coding paradigm resembles a story that retrospectively describes the interrelationship between the emergent factors. This represents a theory that is based on an interpretation from both the homogeneous and the heterogeneous samples.

From the grounded theory analysis, the gap portrayed by the theory is that of the poor quality of food products, and customer dissatisfaction. This originates from asset-related problems, communication problems, poor people management, or top management's inability to commit to effective asset maintenance. When holistically considering all aspects described in $\mathrm{SI}$, the benefits of closing the gap become apparent. Closing the gap will lead to higher quality food products and improved customer satisfaction, as illustrated in Figure 1.

In pursuit of bridging the gap, Figure 1 further illustrates the remaining grounded theory factors. SI has five causal conditions that are problems: the assets, communication, people, leadership, and the need for AM. A coping strategy is derived for the implementation of SI. In this coping strategy, 
the AMS serves as a support system to the TQMS. The coping strategy consists of two parallel sets of activities: one set to achieve strategic integration, which is concerned with top management commitment, and is a top-down approach; and the other set to achieve integration practically by developing a methodology for SI, otherwise known as 'mapping'. The methodology is developed in the form of a comparative mapping of clauses for the ISO 55000 and Foundation for Food Safety Certification (FSSC) 22000 standards. Other situational factors - the intervening conditions influence the coping strategy. These are: customer satisfaction, management systems and standards, and standards selection. During the SI methodology, the ISO 55000 standard is integrated with the FSSC 22000 standard. Since the AMS is compatible for integration with any TQMS, only the integration with FSSC 22000 is demonstrated, based on the input and experience of the study participants. The use of the coping strategy does not come without consequences. It is evident from the participants' input that integration implications (such as certification and auditing of the integrated system; the responsible person for SI; education and training of employees; change management; management principles; and financial implications) need to be considered.

Gap:

Poor quality food products and customer dissatisfaction

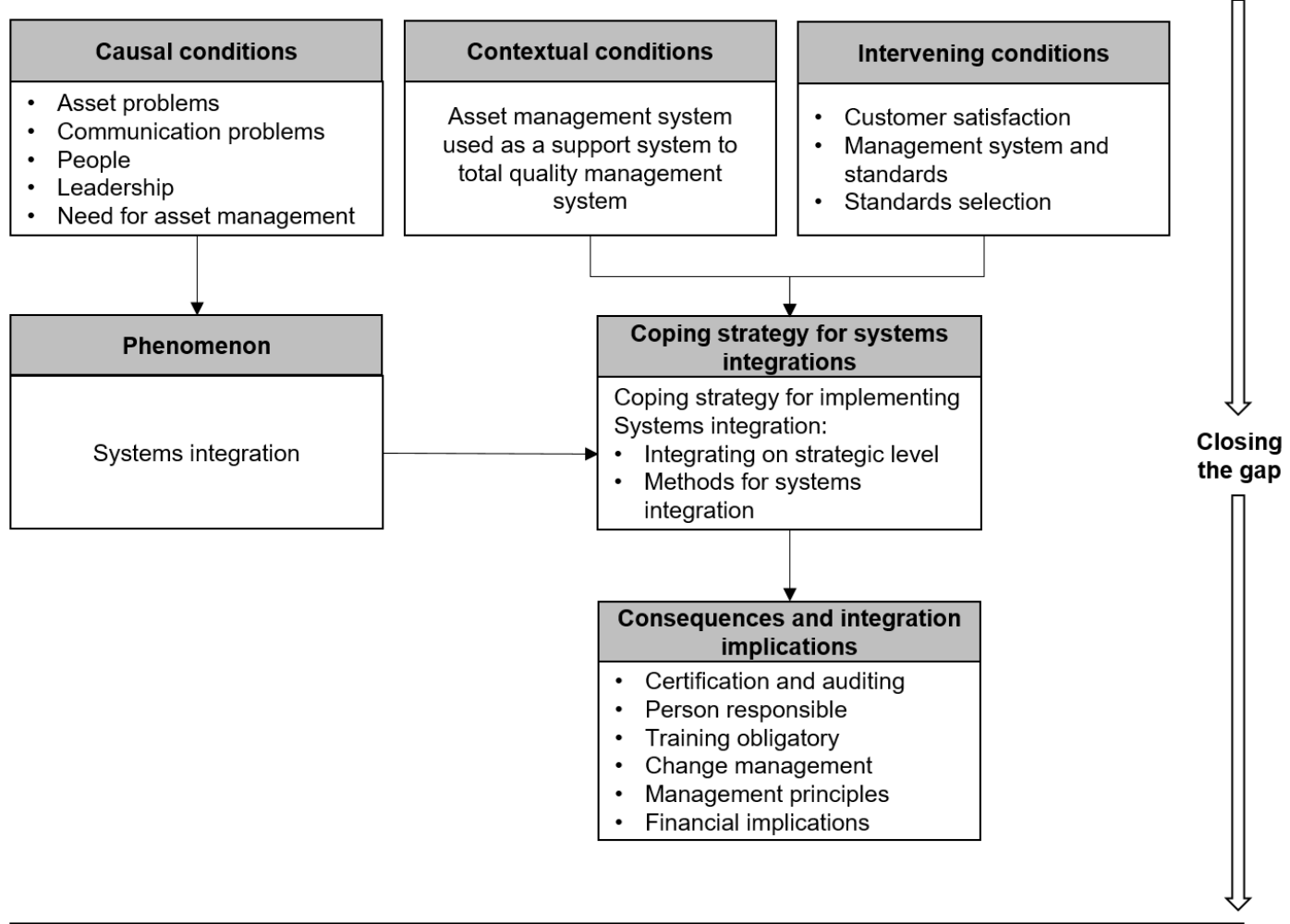

Possible outcome:

Higher quality food production and customer satisfaction

Figure 1: Theoretical model (axial coding paradigm) for integrating asset management with total quality management

\section{RESULTS AND DISCUSSION}

The results of the grounded theory analysis are presented as a guideline for managers who with to implement an integrated $\mathrm{AM}$ and TQM system. This guideline is based on the SI phenomenon identified during the analysis, and is in accordance with the analysed conditions, coping strategy, and consequences. The objective of $\mathrm{SI}$ is to improve the production of quality food products with a supporting system that aligns with effective asset operation and maintenance - ultimately to close the gap so that food organisations can produce higher quality products and improve customer satisfaction (Figure 1). 
The guideline is developed according to the axial coding paradigm. It contains explanatory notes for clarifying the prerequisites to, coping strategy for, and consequences of, $\mathrm{SI}$, and serves to provide an example of an integrated system. The guideline provides guidance for management involved in both the establishment and routine activities of SI in food organisations.

The guideline contains three sections, which consolidate the factors depicted in Figure 1. These sections serve to assist management to understand the conditions for SI, to comprehend how to implement it, and to consider its implications prior to implementation. The guideline further assists management to steer their focus and efforts towards supporting the practices that facilitate the establishment of a holistic and competitive QM capability.

\subsection{Conditions for systems integration implementation}

Two main conditions are required to implement SI successfully. First, an awareness of SI must be created; and second, the causal conditions for SI must be understood. These conditions lead to, and motivate the need for, SI.

\subsubsection{Create systems integration awareness}

The context of SI emerged from the perspective of senior managers. If senior management takes responsibility for SI implementation, they are obliged to create SI awareness among top management by informing them of the need for SI during their annual strategic interventions. Once senior management has introduced the SI to top management, top management must commit to $\mathrm{SI}$ and properly define, document, translate, and communicate it throughout the organisation. Top management's commitment is regarded as important by both the TQM and the AM approaches.

\subsubsection{Gain understanding of causal conditions}

When establishing $\mathrm{SI}$, it is important that managers understand the causal conditions and their relation to SI (Figure 2). Causal conditions are the common issues experienced in the general food industry that lead to the need for SI. The causal conditions that emerged during the study are assetrelated problems; communication problems; the role of people in the process; and commitment from the leadership team.

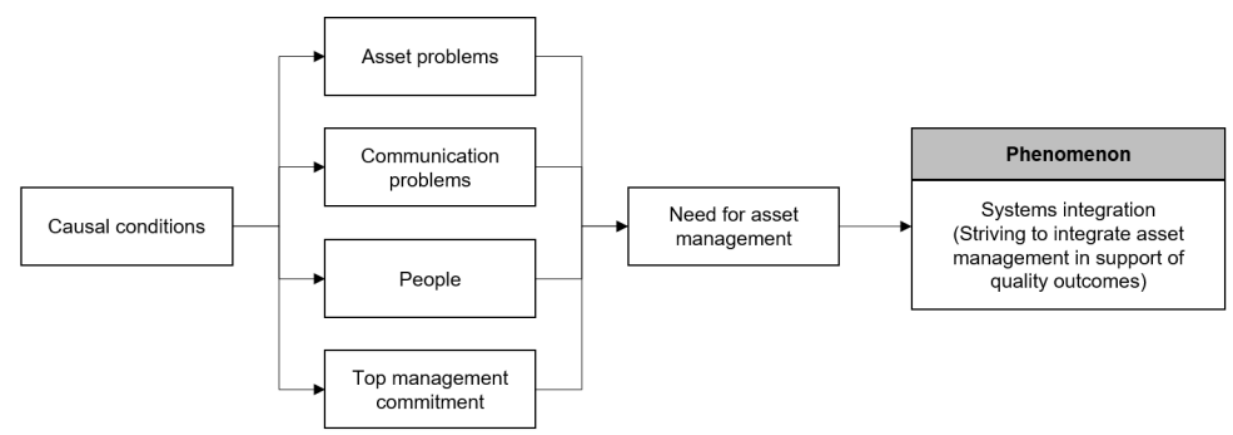

Figure 2: Causal conditions leading to the need for systems integration

Based on the grounded theory analysis, there are two asset classes: human assets and physical assets. Asset problems are therefore classified as those issues related to human and physical assets that food organisations regularly encounter. Human asset problems are perceived as being about uneducated or uninformed people, and the negligent handling of physical assets or the poor operation of these assets by people. Physical asset problems are any causal problem that influences or deviates from the definition of assets - in other words, any condition that prevents potential or actual value from being created by an asset [29]. Physical asset problems have final product implications that negatively affect quality and food safety, thus leading to product quality inconsistency, customer dissatisfaction, and loss of business and reputation. The need for $A M$ is evident from these asset-related problems, since food organisations, in general, lack guidance in the effective management of assets.

People are important to food organisations, and are responsible for managing the successful implementation of systems, the operation and maintenance of physical assets, and ensuring sufficient production performance. People communicate while exercising their responsibilities; and when this communication is ineffective, it leads to asset-related problems. Improper communication 
causes problems for the overall performance and quality of the organisation's final product. The level of the severity of communication problems is different for each organisation, as it depends on organisational culture and leadership. It is evident from the analysis that typical communication issues revolve around the misinterpretation and misunderstanding of employee responsibilities; miscommunication between departments; conflicts of interest between departments; differing levels of competencies; and a negative perception of 'maintenance'. These issues prevail throughout the quality and food safety and engineering departments, most likely due to the existence of interdepartmental silos. Employee involvement, teamwork, and collaboration for continuous improvement are, however, essential. Proper human resources management is therefore critical to overcoming communication issues and to preventing departmental 'silos' and asset-related problems.

AM assists in changing the perceptions of people, and addresses the implications of everyday issues that relate to assets. Therefore the food quality and safety function should benefit from integrating the AMS and TQMS. Integration will support collaboration between departments, which in turn will break down inter-departmental barriers and align focus areas and key performance indicators.

As implied through the requirement of awareness, the commitment of the leadership and top management needs to be established to ensure that resistance to change and everyday issues are resolved promptly. The AMS provides a base to assist leaders and senior and top management to resolve issues that food organisations typically encounter. The commitment of the leadership and top management is paramount to provide sustainable AM, which will ultimately improve systems and overall business outcomes, and increase product quality and safety.

\subsubsection{Motivate the need for systems integration}

Food organisations are lagging behind other industries that have adopted AM practices. Food organisations should recognise that the focus on asset operation, maintenance, and exploitation is as important as the focus on food quality and food safety, due to the significant correlation between achieving high-quality and food-safe products, and AM activities.

The South African food industry, like others globally, experience competitive pressure and stringent regulatory requirements relating to quality and food safety. Due to the complexities involved in food production, the industry is challenged to manufacture consistent quality food products that are reproduced almost precisely. The need, however, is to remain competitive and to ensure customer satisfaction. AM provides support for this, and food organisations should integrate $A M$ to improve efficiency in production, to compete with the international market, and to deliver high product quality. AM provides a competitive advantage, and simultaneously generates improvements in other aspects of the food industries' TQMS. The relationship between causal conditions, the need for AM and food organisations' drive towards production precision, and the need for $\mathrm{SI}$ is motivated on this basis. Integration of the AMS and TQMS provides positive inputs to food organisations' existing TQMS, while allowing them to improve their competitive position through improved quality of the product, efficiency of equipment, and productivity of the people.

\subsection{Systems integration implementation}

For successful SI implementation, a coping strategy is required. The coping strategy represents the SI implementation process, and consists of two coping strategy activities. Figure 3 illustrates the relationships between all the factors required to develop, intervene, and describe the coping strategy for SI.

\subsubsection{Understand the context for developing the coping strategy}

$\mathrm{SI}$ in food organisations is dependent on the organisation's capacity for growth, its organisational culture, its maturity and experience with systems integration, and its ability to implement systems successfully. Where food organisations experience limitations in these areas, they are likely to struggle to implement an AMS and TQMS as two separate systems. It is evident from the analysis that the AMS should be implemented as a supportive system to TQMS. This is presented as the coping strategy for implementing an integrated AMS and TQMS, where it is more feasible to align the standards rather than to implement and manage each standard separately.

\subsubsection{Consider conditions influencing the coping strategy}

Conditions that influence the coping strategy need to be considered. These conditions are customer satisfaction, management systems and standards, and standards selection. 
To keep customers satisfied, it is important for food organisations to provide them with proof of their commitment to deliver high-quality and food-safe products. To illustrate their commitment, food organisations pursue certification for certain systems. The TQMS is well-developed in the food industry and should therefore be established, since it provides a framework for achieving quality and safe food products. Prior to establishing a commitment to the TQMS, it is essential to understand the demands and requirements of the organisation's customers. It is important to note that the structure of the TQMS will differ for food organisations in terms of their decisions about organisational focus, market type, and standard acceptance. Food organisations should therefore decide whether they will be focusing on food safety, quality, environmental issues, or health and safety - or a combination of these objectives. They should determine whether they will produce products privately, nationally, or internationally, and they should decide which standard certification should be pursued prior to establishing their TQMS. These preliminary requirements represent the business objectives of the food organisation and, once established, they may proceed with selecting relevant standards to design their TQMS.

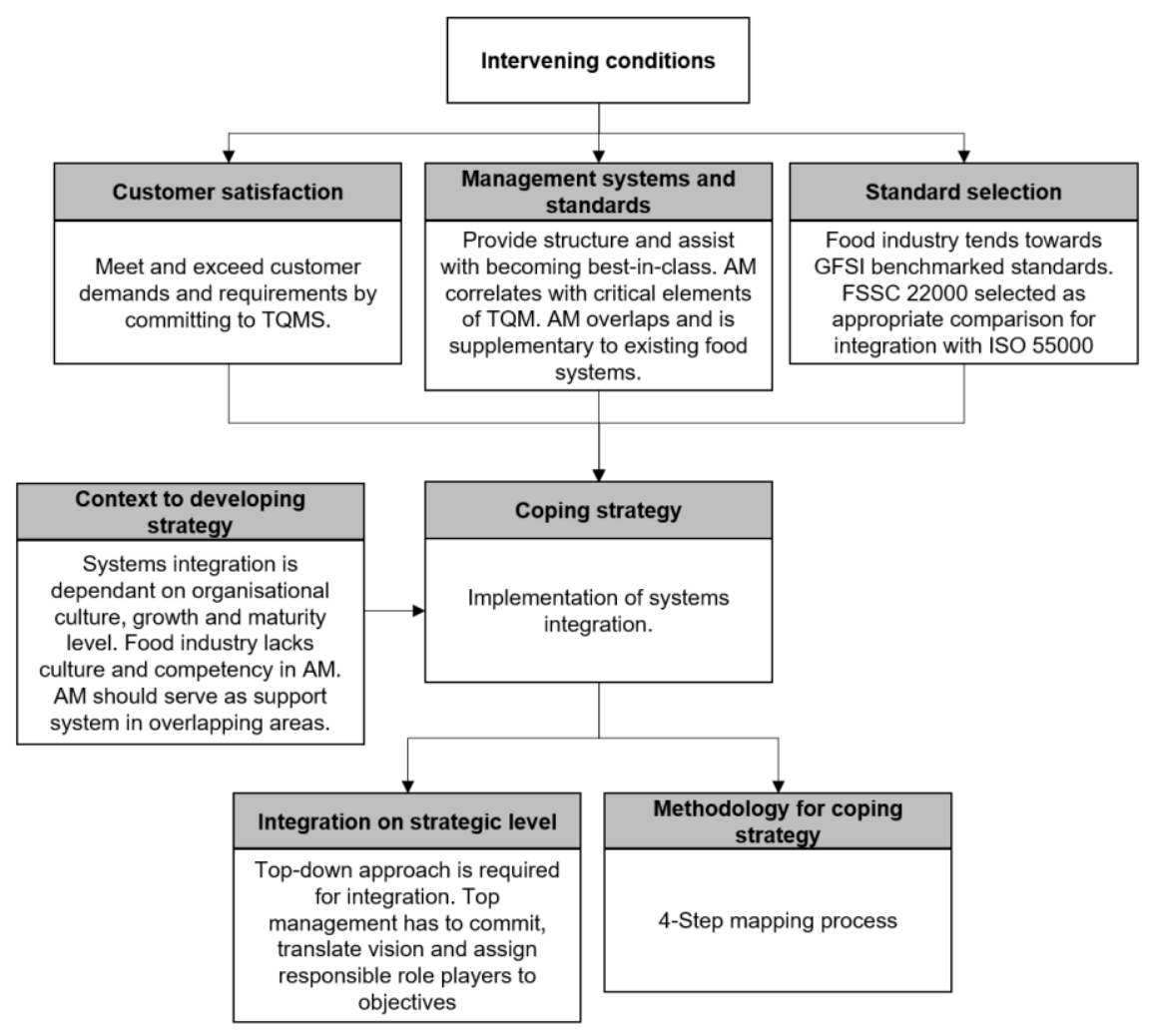

Figure 3: Relationships supporting the coping strategy for systems integration

The AMS provides the structure to support the TQMS. AM is known for its structure, which food organisations generally lack in their management systems. Incorporating the structured AMS will provide additional benefits for realising good quality results. It will also contribute to allowing food organisations to improve their competitiveness. The AMS is compatible to integration with food systems based on both being focused on people, processes, and decision-making; both being focused on continuous improvements; both addressing maintenance issues, such as corrective and preventative maintenance and maintenance schedules; and both being management systems that encompass similar management models with similar processes.

When designing the TQMS, it needs to be recognised that most customers value organisations that are benchmarked by the global food safety initiative (GFSI). GFSI-benchmarked standards are, therefore, considered for SI. The GFSI approves five standards: the British Retail Consortium (BRC), a global standard for food safety; the International Food Standard (IFS); the Safe Quality Food Standard (SQF); the Food Safety System Certification (FSSC) 22000; and the Dutch Hazard Analysis and Critical Control Point (HACCP)-based food safety system. The objective of SI is to incorporate the AMS into one of these five GFSI-benchmarked standards. Based on data and industry norms, FSSC 
22000 is the most appropriate TQM standard for integration with the AM standard ISO 55000 . It is possible, however, to integrate ISO 55000 with any other relevant GFSI food system. For this guideline, only the integration of FSSC 22000 and ISO 55000 is presented as an example.

\subsubsection{Coping strategy for implementing systems integration}

The coping strategy for integrating and implementing the FSSC 22000 and ISO 55000 standards is presented, and an example of the integrated system is provided in Appendix A. Based on the context and intervening conditions (3.2.1 and 3.2.2), the process of the coping strategy is described using two parallel coping activities: integration at a strategic level, and the methodology for SI.

At a strategic level, top management should commit to SI to integrate ISO 55000 with FSSC 22000. A 'top-down' approach to successfully achieving $\mathrm{SI}$ is required, such that top management needs to translate and communicate the vision for SI to the entire organisation, while those responsible for SI will need to ensure that the objectives and goals of the vision are met.

The methodology for SI implementation follows a four-step mapping process in which the clauses for the ISO 55001 and FSSC 22000 standards are compared and integrated. The methodology for SI is as follows:

Step 1: Introduction to standards

a. Understand the outline of the ISO 55000 standard.

b. Understand the outline of the FSSC 22000 standard.

Step 2: Clause incorporation

a. Identify the correspondence between each clause of ISO 55001 and FSSC 22000.

b. Once the relevant clauses are identified, determine their relevance, and decide whether to incorporate or to ignore each one in turn.

c. If it is agreed to incorporate the clause, proceed with step 3; if it is agreed to ignore the clause, repeat step 2 until a relevant clause is identified.

Step 3: Strategic development

a. Incorporate the relevant ISO 55001 clause into FSSC 22000.

b. Refer to FSSC 22000 [30] and ISO 55001 [31] if overlapping clauses require further explanation.

Step 4: Confirmation

a. Repeat steps 1 to 3 for confirmation.

b. If deemed necessary, incorporate appropriate revisions and improvements.

By following the simple mapping process, managers will be able to understand the mutual benefits of integrating ISO 55000 with FSSC 22000. Refer to Appendix A for the integrated system.

Most clauses of the ISO 55001 standard provide support and promote specific areas of the FSSC 22000 standard; the FSSC 22000 lacks guidance and structure in support of managing assets and hazards related to food products and processes [31]. FSSC 22000 is therefore supplemented by ISO 55000 to assist in managing the organisation's assets in a more proactive and improved manner.

The integrated system (Appendix A) illustrates the correspondence between ISO 55000 and FSSC 22000 , and explains how SI is performed. The integrated system should provide assistance during the strategic implementation of the FSSC 22000 standard, to consider collaboratively the relevant and essential aspects of the ISO 55000 standard to obtain synergistic results. It further serves as the foundation for developing other possible integrated systems.

\subsection{Systems integration consequences and implications}

Management should consider the consequences and integration implications of applying the coping strategy for implementing SI. These consequences and implications are presented in six categories, illustrated in Figure 4. Each category is discussed briefly.

Certification and auditing are important processes by which food organisations ensure competitiveness. Certification in standards is predominantly driven by customer requirements. Food organisations generally strive for certification to increase their market share and profitability. External auditing is required for certification. Although organisations can be certified in some standards without being audited, it is important that internal auditing is conducted to ensure compliance with the minimum legislative requirements. Sustainable $A M$ is required to ensure the 
effective application of ISO 55000 and to attain benefits from incorporating it into food standards. On this basis, and due to the novelty of integrating ISO 55000 with TQMS in food organisations, internal auditing is advised to ensure conformance with the ISO 55000 requirements. Internal auditing will further support the implementation of SI by supporting the existing TQMS and the FSSC 22000 standard that might already be in place.

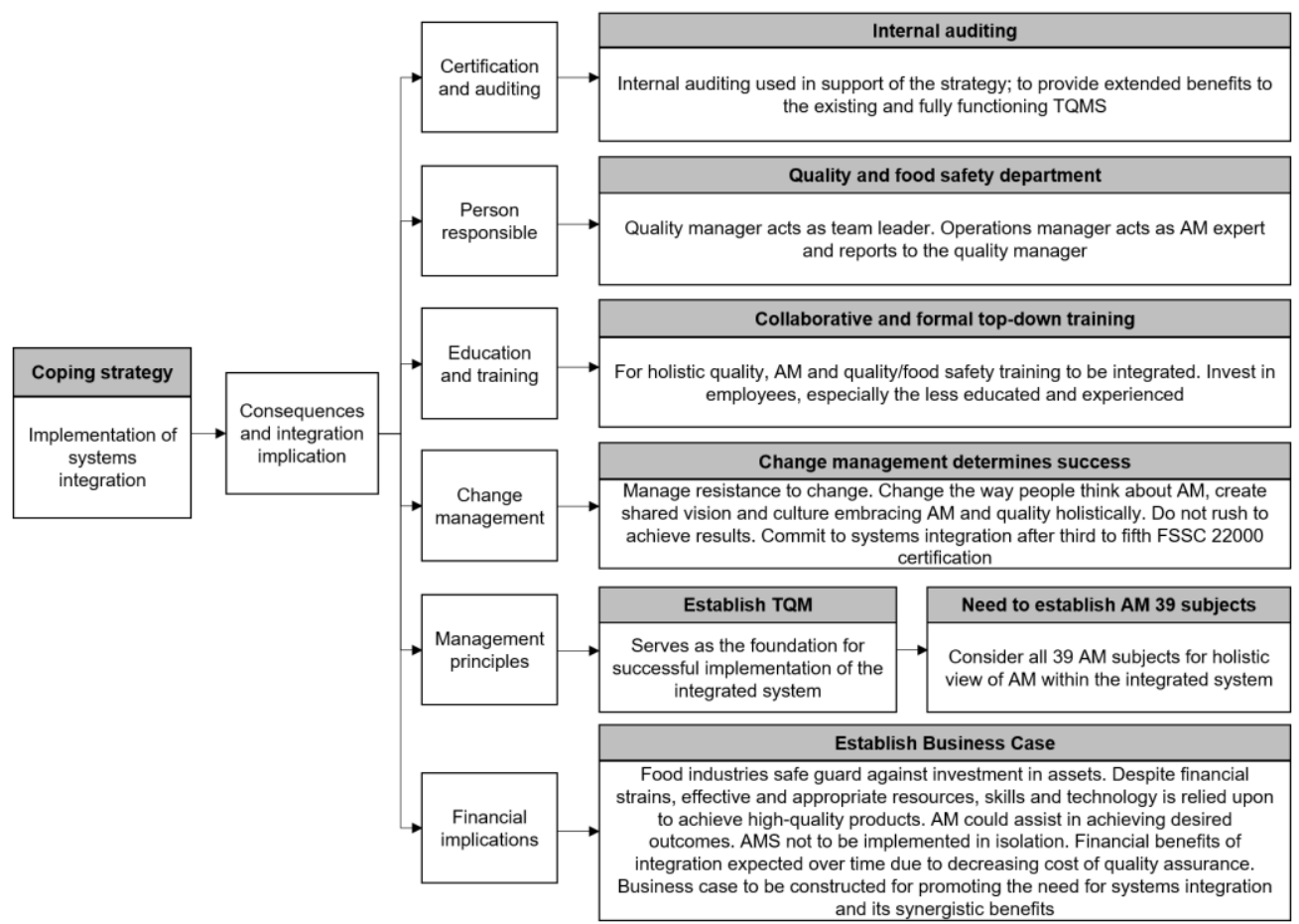

Figure 4: Systems integration - consequences and implications

The quality assurance (QA) manager should lead the food safety team, and this team should lead the SI initiative. The QA manager should be responsible for administering the integrated system, for keeping records, and for assigning activities or tasks to the members of the food safety team. Where an organisation employs a technical manager, that person should be responsible for SI. This is because the technical manager has a strategic perspective on the organisation, with accountability for both the TQMS and AM. The technical manager should delegate SI and assign responsibilities to the QA manager, who remains the leader of the food safety team, and who should appoint an expert in $A M$ to provide guidance to the team about the AMS. This role should be fulfilled by the engineering manager (or, if such a position does not exist, an equally capable person). The engineering manager should be responsible for ensuring that the integrated system complies with the relevant ISO 55000 requirements. The engineering manager should acquire any necessary knowledge about $A M$ and its practices to support SI, and should report SI responsibilities to the QA manager or the technical manager. Neither the QA nor the technical managers need to have in-depth knowledge of AM. The multidisciplinary nature of the food safety team provides the supporting insight for AM and for TQMS. Each representative of the team should use the integrated system as a foundation for achieving their daily activities, all of which are administrated by the system's administrator (the QA manager).

Most food industries rely on employees to physically operate assets, such as production equipment and machinery. This often leads to product specification deviations. By contrast, the engineering industry relies predominantly on automated assets with limited human intervention. The result is more precise, and better quality, production outputs. The food industry can leverage similar automation opportunities through the integration of the AM and TQM systems. Due to the manual operation of assets in the food industry, providing education and training opportunities for the quality, food safety, and engineering departments is essential. These departments should be supported with the necessary knowledge and skills in AM. Knowledge and skills development are especially important for engineering managers, since they have the responsibility of providing the AM expertise during SI. Providing training and skills development opportunities to employees who 
operate assets will further ensure that asset operation and performance are in accordance with the AMS.

The successful implementation of $\mathrm{SI}$ is dependent on the food organisation's capacity to grow, the organisational culture that they envisage, their level of maturity in terms of systems, and their ability to manage change. Top management should define and envisage a collaborative culture that allows for flexibility, control, sustainability, and continued improvement across all levels of competencies. During the implementation of $\mathrm{SI}$, the organisation should not attempt to fast-track the process. SI is a progressive, systematic process with which various aspects of complexity are associated. The change associated with SI should therefore not be underestimated, and sufficient time should be allowed to ensure the sustainability of the integrated system. The level of maturity for SI in food organisations, as well as workforce competency levels, also influences the ability, effectiveness, and efficiency of implementing the integrated system. Organisations may only commit to SI once they have reached a certain level of maturity; this could be only after their third to fifth successful FSSC 22000 accreditation.

Management principles serve as building blocks to achieve the successful implementation of any system. Such principles should be established before initiating SI. In the AM literature, there are six AM category groups consisting of 39 AM subjects [32]. These subjects should be considered during the integration process for a holistic coverage of AM activities. Not all 39 AM subjects will be equally relevant to all functions in the TQMS, but it is necessary to consider these to comply with the ISO 55000 standard and the proposed integrated system.

Although establishing an $A M$ culture is likely to be expensive in both time and resources, long-term financial benefits will be realised. Financial decision-making is important to food organisations, and includes decisions related to asset investments and maintenance. There are various financial implications to implementing SI. These implications include, but are not limited to:

- $\quad$ possible employment of new or outsourced employees;

- $\quad$ training obligations and opportunities;

- $\quad$ auditing accreditations; and

- $\quad$ investments in new, and repair of, existing assets.

Although food organisations realise the importance of investing in their assets and in maintaining them, the concern about financial instability and the influence of finances on decision-making and possible asset investments persists. When investing in assets, the financial capability of the investment should be determined. It is advised that a business case be developed to safeguard the financial implications of SI and to promote the potential monetary and non-monetary benefits of the integrated system.

It is likely that $\mathrm{SI}$, in conjunction with effective $\mathrm{AM}$, will improve the effectiveness of both process management and organisational profits, since it will have a positive influence on the cost of quality over time. SI will also create a more effective, efficient, and productive production process that will prevent product scrapping, product rework, product recall, and defective products from re=occurring.

\section{CONCLUSION}

food industry in general is determined to deliver high-quality and safe food products in response to stringent regulatory and customer demands. This study establishes that food industries in South Africa, like their international counterparts, rely on high-quality performance to sustain their competitive advantage. It argues that an AMS is an important management approach that could provide extended benefits to an existing TQMS, especially as the food industry is a capital assetintensive industry that relies on effective production processes to achieve desirable outcomes.

Besides the similarities between the asset and total quality management systems, and their recognition and independent implementation in industry, the study shows that there is a lack of knowledge and understanding in food organisations about how to integrate these systems to gain food quality benefits. For this reason, the study offers a grounded theory based on food quality and asset management expertise to integrate $A M$ with TQM. From the results, a theoretical guideline for managers is developed and presented. This guideline is based on the need to improve food quality 
and customer satisfaction, and explains systems integration and the causal conditions for the integration. The guideline also presents the two parallel parts of a coping strategy for integrating $A M$ and TQM systems: strategic integration supported by top management, and the mapping of the $A M$ and TQM system requirements. It also offers managers knowledge about the potential consequences of the systems integration. These include certification and auditing, having responsible role players, providing education and training, managing change, establishing management principles, and taking financial issues into consideration.

The present study also has some limitations. With ISO 55000 being a recently developed standard, no participating food organisation that is ISO 55000 certified could be found to include in the study. The ISO 55000 insights are therefore based on expertise outside the food industry. Due to cost and time considerations, the study could not be generalised beyond the South African food industry, although it is expected that results will only differ marginally from studies in other similar food industries. Future research studies should therefore build on this research to include experience from ISO 55000 certified food organisations, and to include other global food industries.

\section{REFERENCES}

[1] Beardsell, M.L. \& Dale, B.G. 1999. The relevance of total quality management in the food supply and distribution industry: A study. British Food Journal, 101(3), 190-201. http://doi.org/10.1108/00070709910269802

[2] Kaur, M., Singh, K. \& Singh Ahuja, I. 2012. An evaluation of the synergic implementation of TQM and TPM paradigms on business performance. International Journal of Productivity and Performance Management, 62(1), 66-84.

[3] Kaynak, H. 2003. The relationship between total quality management practices and their effects on firm performance. Journal of Operations Management, 21(4), 405-435.

[4] Kedar, A.P., Lakhe, R.R., Deshpande, V.S., Washimkar, P.V. \& Wakhare, M.V. 2008. A comparative review of TQM, TPM and related organisational performance improvement programs. In 2008 First International Conference on Emerging Trends in Engineering and Technology (725-730). http://doi.org/10.1109/ICETET.2008.133

[5] Dora, M., Kumar, M., van Goubergen, D., Molnar, A. \& Gellynck, X. 2013. Operational performance and critical success factors of lean manufacturing in European food processing SMEs. Trends in Food Science \& Technology, 31(2), 156-164.

[6] International Standards Organization [Online]. 2005. ISO 9001:2008(E), Quality management systems: Requirements.

[7] Luning, P.A., Marcelis, W.J. \& Jongen, W.M.F.. 2002. Food quality management: A techno-managerial approach. Wageningen Academic Publishers, Wageningen, Netherlands.

[8] Islam, A. \& Haque, A. 2012. Pillars of TQM implementation in manufacturing organization: An empirical study. Journal of Research in International Business and Management, 2(5), 128-141.

[9] Schneider, J., Gaul, A.J., Neumann, C., Hogräfer, J., Wellßow, W., Schwan, M. \& Schnettler, A. 2006. Asset management techniques. International Journal of Electrical Power \& Energy Systems, 28(9), 643654.

[10] Tsarouhas, P. 2007. Implementation of total productive maintenance in food industry: A case study. Journal of Quality in Maintenance Engineering, 13(1), 5-18.

[11] Yusuf, Y., Gunasekaran, A. \& Dan, G. 2007. Implementation of TQM in China and organisation performance: An empirical investigation. Total Quality Management, 18(5), 509-530.

[12] Yusof, S.M. \& Aspinwall, E. 2000. Total quality management implementation frameworks: Comparison and review. Total Quality Management, 11(3), 281-294.

[13] Kriege, L.K., Jooste, J.L. \& Vlok, P.J. 2016. A framework for establishing a human asset register for the improved management of people in physical asset management. South African Journal of Industrial Engineering, 27(4), 77-89. http://doi.org/10.7166/27-4-1549

[14] Schuman, C.A. \& Brent, A.C. 2005. Asset life cycle management: Towards improving physical asset performance in the process industry. International Journal of Operations \& Production Management, 25(6), 566-579.

[15] IAM. 2011. Asset management: An anatomy. Bristol, UK: IAM.

[16] International Standards Organization. 2014. ISO 55000:2014 Asset management: Overview, principles and terminology. Geneva, Switzerland: International Organization for Standardization (ISO).

[17] Woodhouse, J. 2006. Putting the total jigsaw puzzle together: PAS 55 standard for the integrated, optimized management of assets. The Woodhouse Partnership, United Kingdom.

[18] Vanier, D.J. 2001. Why industry needs asset management tools. Journal of Computing in Civil Engineering, 15(1), 35-43.

[19] Thiagaragan, T., Zairi, M., \& Dale, B.G. 2001. A proposed model of TQM implementation based on an empirical study of Malaysian industry. International Journal of Quality \& Reliability Management, 18(3), 289-306.

[20] Powell, T.C. 1995. Total quality management as competitive advantage: A review and empirical study. Strategic Management Journal, 16(1), 15-37. 
[21] Pinto, A., Leite, H., Vidal, P., Pereira, H. \& Santos, J.M. (2013). Path towards PAS-55 in the Portuguese DSO: A working example in the protection and control systems. In Electricity Distribution (CIRED 2013), 22nd International Conference and Exhibition on, 1-4.

[22] Jooste, J.L. \& Vlok, P.J. 2015. A decision support model to determine the critical success factors of asset management services. South African Journal of Industrial Engineering, 26(1), 27-43.

[23] Mitchell, J.S., Bond, T.H., Nodianos, N. \& Brotherton, T. 2002. Physical asset management handbook. Houston: Clarion Technical Publishers.

[24] McDonald, I., Zairi, M. \& Ashari Idris, M. 2002. Sustaining and transferring excellence: A framework of best practice of TQM transformation based on winners of Baldrige and European Quality Awards. Measuring Business Excellence, 6(3), 20-30.

[25] McElroy, R.S. 1999. Update on national asset management initiatives: Facilitating investment decisionmaking. In Innovations in Urban Infrastructure Seminar of the APWA International Public Works Congress (1-10).

[26] Malano, H.M., Chien, N.V. \& Turral, H.N. 1999. Asset management for irrigation and drainage infrastructure - principles and case study. Irrigation and Drainage Systems, 13(2), 109-129.

[27] Mann, R., Adebanjo, O. \& Kehoe, D. 1999. An assessment of management systems and business performance in the UK food and drinks industry. British Food Journal, 101(1), 5-21.

[28] Corbin, J.M., Strauss, A.L. \& Strauss, A.L. 2008. Basics of qualitative research: Techniques and procedures for developing grounded theory. Los Angeles, Calif: Sage Publications.

[29] Das, A., Kumar, V. \& Kumar, U. 2011. The role of leadership competencies for implementing TQM: An empirical study in Thai manufacturing industry. International Journal of Quality \& Reliability Management, 28(2), 195-219.

[30] Foundation for Food Safety Certification [Online]. 2013. FSSC 22000: Certification scheme for food safety systems in compliance with ISO 22000:2005 and BSI-PAS 220:2008. Foundation for Food Safety Certification.

[31] International Standards Organization. 2014. ISO 55001:2014 Asset management - Management systems - Requirements. Geneva, Switzerland: International Organization for Standardization (ISO).

[32] GFMAM. 2014. The asset management landscape. Zürich: GFMAM. 
APPENDIX A: ISO 55000 INTEGRATION WITH FSSC 22000

\begin{tabular}{|c|c|c|c|c|}
\hline FSSC 22000:2005 & Clause & Clause & ISO 55001:2014 & Additional Notes \\
\hline \multicolumn{5}{|l|}{ Introduction } \\
\hline Scope & 1 & 1 & Scope & \\
\hline Normative references & 2 & 2 & Normative references & \\
\hline Terms and definitions & 3 & 3 & Terms and definitions & \\
\hline $\begin{array}{l}\text { Food safety management } \\
\text { system }\end{array}$ & 4 & 4 & Context of the organisation & \\
\hline \multirow[t]{4}{*}{ General requirements } & 4.1 & 4.1 & $\begin{array}{l}\text { Understanding the organisation } \\
\text { and its context }\end{array}$ & \\
\hline & & 4.2 & $\begin{array}{l}\text { Understanding the needs and } \\
\text { expectations of stakeholders }\end{array}$ & \\
\hline & & 4.3 & $\begin{array}{l}\text { Determining the scope of the } \\
\text { asset management system }\end{array}$ & \\
\hline & & 4.4 & Asset management system & \\
\hline \multirow[t]{2}{*}{ Documentation requirements } & 4.2 & 7.5 & Information requirements & \\
\hline & & 7.6 & Documented information & \\
\hline General & 4.2 .1 & 7.6.1 & General & \\
\hline Control of documents & 4.2 .2 & 7.6 .3 & $\begin{array}{l}\text { Control of documented } \\
\text { information }\end{array}$ & \\
\hline Control of records & 4.2 .3 & 7.6 .2 & Creating and updating & \\
\hline Management responsibility & 5 & 5 & Leadership & \\
\hline Management commitment & 5.1 & 5.1 & Leadership and commitment & \\
\hline Food safety policy & 5.2 & 5.2 & Policy & \\
\hline \multirow[t]{5}{*}{$\begin{array}{l}\text { Food safety management } \\
\text { system planning }\end{array}$} & 5.3 & 6 & Planning & \\
\hline & & 6.1 & $\begin{array}{l}\text { Actions to address risks and } \\
\text { opportunities for the asset } \\
\text { management system }\end{array}$ & \\
\hline & & 6.2 & $\begin{array}{l}\text { Asset management objectives } \\
\text { and planning to achieve these }\end{array}$ & \\
\hline & & 6.2 .1 & Asset management objectives & \\
\hline & & 6.2 .2 & $\begin{array}{l}\text { Planning to achieve asset } \\
\text { objectives }\end{array}$ & \\
\hline Responsibility and authority & 5.4 & 5.3 & $\begin{array}{l}\text { Organisational roles, } \\
\text { responsibilities, and } \\
\text { authorities }\end{array}$ & \\
\hline Food safety team leader & 5.5 & & & $\begin{array}{l}\text { ISO } 550005.3 .2 \\
\text { refers to the } \\
\text { establishment of } \\
\text { the person } \\
\text { responsible for the } \\
\text { integrated system. }\end{array}$ \\
\hline Communication & 5.6 & 7.4 & Communication & \\
\hline External communication & 5.6 .1 & & & \multirow{2}{*}{$\begin{array}{l}\text { ISO } 55002 \text { 7.4.1, } \\
7.4 .2 \text { and 7.4.3 }\end{array}$} \\
\hline \multirow[t]{2}{*}{ Internal communication } & 5.6 .2 & 7.5 & Information requirements & \\
\hline & & 8.2 & Management of change & \\
\hline $\begin{array}{l}\text { Emergency preparedness and } \\
\text { response }\end{array}$ & 5.7 & 10.2 & Preventive action & \\
\hline Management review & 5.8 & 9.3 & Management review & \\
\hline General & 5.8 .1 & & & ISO 550029.3 .1 \\
\hline Review input & 5.8 .2 & & & $\begin{array}{l}\text { ISO } 550029.3 .2 \\
\text { and } 9.3 .3\end{array}$ \\
\hline Review output & 5.8 .3 & & & $\begin{array}{l}\text { ISO } 550029.3 .4 \\
\text { and } 9.3 .5\end{array}$ \\
\hline
\end{tabular}




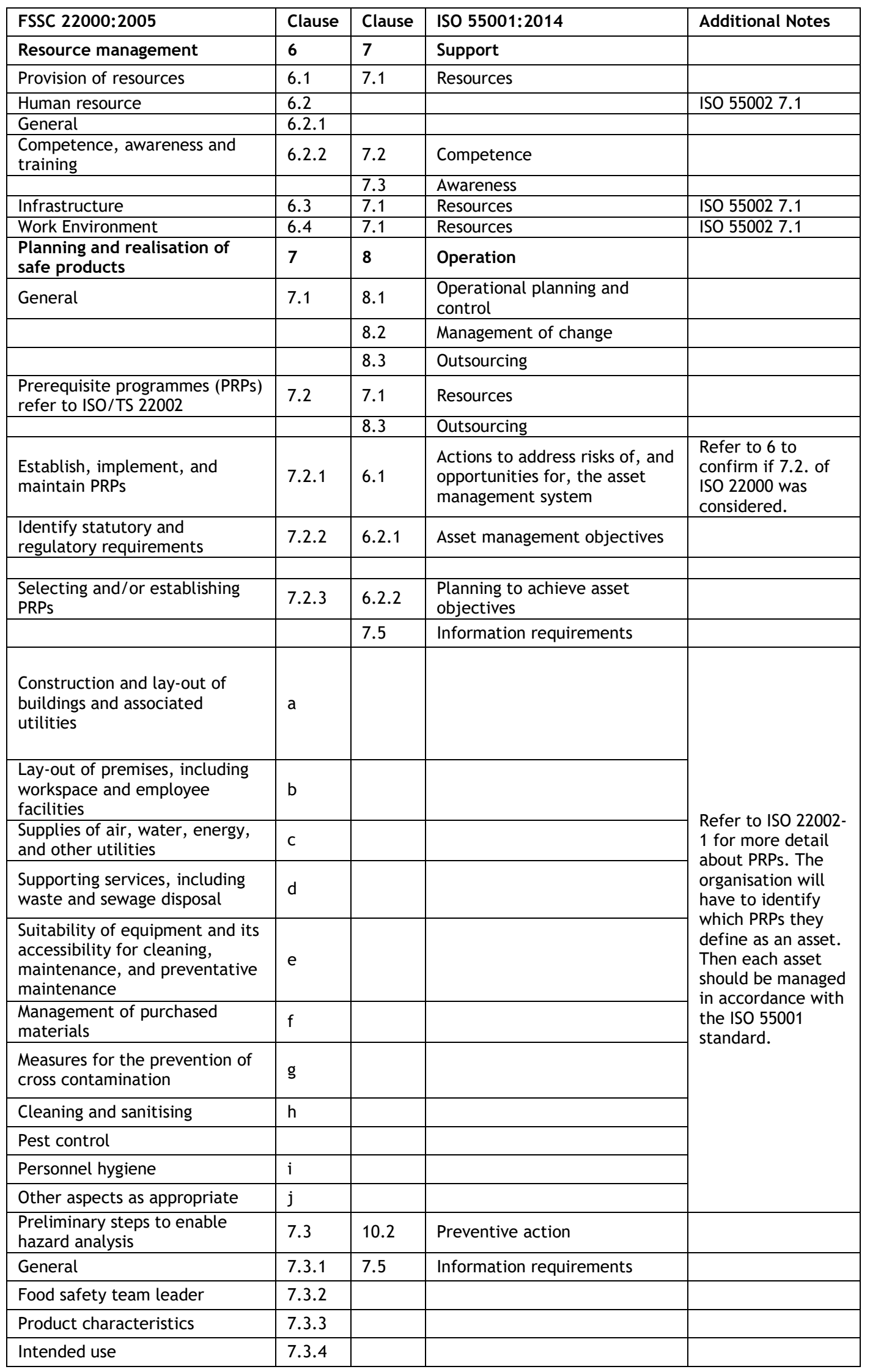




\begin{tabular}{|c|c|c|c|c|}
\hline FSSC 22000:2005 & Clause & Clause & ISO 55001:2014 & Additional Notes \\
\hline $\begin{array}{l}\text { Flow diagrams, process steps, } \\
\text { and control measures }\end{array}$ & 7.3 .5 & 6 & Planning & $\begin{array}{l}\text { Clause } 6 \text { of ISO } \\
55001 \text { must be } \\
\text { considered during } \\
\text { flow diagram } \\
\text { establishment }\end{array}$ \\
\hline Hazard analysis & 7.4 & & & $\begin{array}{l}\text { Refer to the ISO } \\
55001 \text { in general. }\end{array}$ \\
\hline General & 7.4.1 & 6.1 & $\begin{array}{l}\text { Actions to address risks and } \\
\text { opportunities for the asset } \\
\text { management system }\end{array}$ & \\
\hline $\begin{array}{l}\text { Hazard identification and } \\
\text { determination of acceptable } \\
\text { levels }\end{array}$ & 7.4 .2 & 6.1 & $\begin{array}{l}\text { Actions to address risks and } \\
\text { opportunities for the asset } \\
\text { management system }\end{array}$ & \\
\hline Hazard assessment & 7.4 .3 & 6.1 & $\begin{array}{l}\text { Actions to address risks and } \\
\text { opportunities for the asset } \\
\text { management system }\end{array}$ & \\
\hline \multirow[t]{2}{*}{$\begin{array}{l}\text { Selection and assessment of } \\
\text { control measures }\end{array}$} & 7.4 .4 & 6.2 .1 & Asset management objectives & \\
\hline & & 6.2 .2 & $\begin{array}{l}\text { Planning to achieve asset } \\
\text { objectives }\end{array}$ & \\
\hline $\begin{array}{l}\text { Establishing the operational } \\
\text { prerequisite programmes (PRPs) }\end{array}$ & 7.5 & 8.1 & $\begin{array}{l}\text { Operational planning and } \\
\text { control }\end{array}$ & $\begin{array}{l}\text { This refers to the } \\
\text { management of the } \\
\text { operational } \\
\text { prerequisite } \\
\text { programmes } \\
\text { (OPRPs) considered } \\
\text { in clause } 7.2 \text { of ISO } \\
22002 \text { to prevent } \\
\text { cross } \\
\text { contamination or } \\
\text { the introduction of } \\
\text { hazards to the } \\
\text { product. }\end{array}$ \\
\hline Establishing the HACCP plan & 7.6 & & & $\begin{array}{l}\text { This refers to the } \\
\text { management of the } \\
\text { critical control } \\
\text { points (CCPs) } \\
\text { identified in clause } \\
7.4 \text { of ISO } 22002 \text { to } \\
\text { prevent cross } \\
\text { contamination or } \\
\text { the introduction of } \\
\text { hazards to the } \\
\text { product. }\end{array}$ \\
\hline HACCP plan & 7.6.1 & $\begin{array}{l}6.2 .2 \\
8\end{array}$ & $\begin{array}{l}\text { Planning to achieve asset } \\
\text { objectives } \\
\text { Operations }\end{array}$ & \\
\hline $\begin{array}{l}\text { Identification of critical control } \\
\text { points (CCPs) }\end{array}$ & 7.6 .2 & $\begin{array}{l}6.1 \\
8\end{array}$ & $\begin{array}{l}\text { Actions to address risks and } \\
\text { opportunities for the asset } \\
\text { management system } \\
\text { Operations }\end{array}$ & \\
\hline $\begin{array}{l}\text { Determination of critical limits } \\
\text { for critical control points }\end{array}$ & 7.6 .3 & $\begin{array}{l}6.2 .1 \\
8\end{array}$ & $\begin{array}{l}\text { Asset management objectives } \\
\text { Operations }\end{array}$ & \\
\hline $\begin{array}{l}\text { Systems for the monitoring of } \\
\text { critical control points }\end{array}$ & 7.6 .4 & 9.1 & $\begin{array}{l}\text { Monitoring, measurements, } \\
\text { analysis, and evaluation }\end{array}$ & \\
\hline $\begin{array}{l}\text { Actions when monitoring results } \\
\text { exceed critical limits }\end{array}$ & 7.6 .5 & $\begin{array}{l}10.1 \\
10.2\end{array}$ & $\begin{array}{l}\text { Nonconformity and corrective } \\
\text { action } \\
\text { Preventive action }\end{array}$ & \\
\hline $\begin{array}{l}\text { Updating of preliminary } \\
\text { information and documents } \\
\text { specifying the PRPs and the } \\
\text { HACCP plan }\end{array}$ & 7.7 & & & \\
\hline Verification planning & 7.8 & 9.1 & $\begin{array}{l}\text { Monitoring, measurements, } \\
\text { analysis, and evaluation }\end{array}$ & \\
\hline Traceability system & 7.9 & & & \\
\hline Control of nonconformity & 7.10 & & & \\
\hline
\end{tabular}




\begin{tabular}{|c|c|c|c|c|}
\hline FSSC 22000:2005 & Clause & Clause & ISO 55001:2014 & Additional Notes \\
\hline Corrections & 7.10 .1 & 10.1 & $\begin{array}{l}\text { Nonconformity and corrective } \\
\text { action }\end{array}$ & \\
\hline \multirow[t]{2}{*}{ Corrective actions } & 7.10 .2 & 10.1 & $\begin{array}{l}\text { Nonconformity and corrective } \\
\text { action }\end{array}$ & \\
\hline & & 10.2 & Preventive action & $\begin{array}{l}\text { ISO } 22000 \text { does not } \\
\text { describe } \\
\text { preventative } \\
\text { actions in detail. } \\
\text { Refer to ISO } 55002 \text {, } \\
\text { clause } 10.2 \text { in } \\
\text { support }\end{array}$ \\
\hline $\begin{array}{l}\text { Handling of potentially unsafe } \\
\text { products }\end{array}$ & 7.10 .3 & 10.1 & $\begin{array}{l}\text { Nonconformity and corrective } \\
\text { action }\end{array}$ & \\
\hline Withdrawals & 7.10 .4 & 10.1 & $\begin{array}{l}\text { Nonconformity and corrective } \\
\text { action }\end{array}$ & \\
\hline $\begin{array}{l}\text { Validation, verification, and } \\
\text { improvement of food safety } \\
\text { management system }\end{array}$ & 8 & 9 & Performance evaluation & \\
\hline General & 8.1 & 9.1 & $\begin{array}{l}\text { Monitoring, measurements, } \\
\text { analysis, and evaluation }\end{array}$ & \\
\hline $\begin{array}{l}\text { Validation of control measures } \\
\text { combinations }\end{array}$ & 8.2 & 9.1 & $\begin{array}{l}\text { Monitoring, measurements, } \\
\text { analysis, and evaluation }\end{array}$ & \\
\hline $\begin{array}{l}\text { Control of monitoring and } \\
\text { measuring }\end{array}$ & 8.3 & 9.1 & $\begin{array}{l}\text { Monitoring, measurements, } \\
\text { analysis, and evaluation }\end{array}$ & \\
\hline $\begin{array}{l}\text { Food safety management } \\
\text { system verification }\end{array}$ & 8.4 & & & \\
\hline Internal audit & 8.4 .1 & 9.2 & Internal audit & \\
\hline $\begin{array}{l}\text { Evaluation of individual } \\
\text { verification results }\end{array}$ & 8.4 .2 & & & \\
\hline $\begin{array}{l}\text { Analysis of results of } \\
\text { verification results }\end{array}$ & 8.4 .3 & & & \\
\hline \multirow[t]{3}{*}{ Improvement } & 8.5 & 10 & Improvement & \\
\hline & & 10.1 & $\begin{array}{l}\text { Nonconformity and corrective } \\
\text { action }\end{array}$ & \\
\hline & & 10.2 & Preventive action & \\
\hline Continual improvement & 8.5 .1 & 10.3 & Continual improvement & \\
\hline $\begin{array}{l}\text { Updating the food safety } \\
\text { management system }\end{array}$ & 8.5 .2 & & & \\
\hline
\end{tabular}

